\title{
IMMUNE PROTECTION OF SALVINIA MOLESTA D.S. MITCHELL IN FRESHWATER CRAB OZIOTELPHUSA SENEX SENEX BACTERIALLY CHALLENGED WITH AEROMONAS HYDROPHILA
}

\author{
NITHYA TG ${ }^{1 *}$, JAYANTHI J ${ }^{2}$, RAGUNATHAN MG ${ }^{3}$, DEVAKUMAR ${ }^{3}$ \\ ${ }^{1}$ Department of Biotechnology, Faculty of Science and Humanities, SRM University, Chennai, Tamil Nadu, India. ${ }^{2}$ G.S. Gill Research Institute, \\ Guru Nanak College, Chennai, Tamil Nadu, India. ${ }^{3}$ Department of Advanced Zoology and Biotechnology, Guru Nanak College, Chennai, \\ Tamil Nadu, India. Email: nithya.g@ktr.srmuniv.ac.in \\ Received: 17 July 2017, Revised and Accepted: 16 September 2017
}

ABSTRACT

Objective: This is aimed to study the immune protection parameters of freshwater weed Salvinia molesta in bacterially challenged freshwater crab Oziotelphusa senex senex.

Methods: In this present study, ethanolic extract of freshwater weed S. molesta was tested for its ability to induce immunity in bacterial challenged freshwater crab 0 . senex senex. Male and female crabs were challenged with Aeromonas hydrophila in relevant concentrations. The treated groups were allowed to withstand for $96 \mathrm{hrs}$. After relevant incubation time, the hemolymph of the treated crabs was subjected for various hematological, biochemical, and immunological assays.

Results: Total hemocyte count increased on infection at $96 \mathrm{hrs}$, whereas significantly reduced on treatment with S. molesta at $96 \mathrm{hrs}$. All the three cell types of differential hemocytes showed significant positive changes on treatment. Levels of prophenoloxidase decreased significantly on infection and showed a significant increase in treated groups at $96 \mathrm{hrs}$ of treatment.

Conclusion: The present study elucidated the medicinal and pharmaceutical role of $S$. molesta weed which is been subjected to eradication in the recent days. Thus, the plant source can be utilized as an immunomodulatory agent and a better alternative to treat aquatic diseases.

Keywords: Oziotelphusa senex senex, Aeromonas hydrophila, Salvinia molesta, Immunostimulant, total hemocyte count, Differential hemocytes count, Prophenoloxidase.

(c) 2017 The Authors. Published by Innovare Academic Sciences Pvt Ltd. This is an open access article under the CC BY license (http://creativecommons. org/licenses/by/4. 0/) DOI: http://dx.doi.org/10.22159/ajpcr.2017.v10i12.21461

\section{INTRODUCTION}

The growth of aquaculture sector in the recent years and increased demand for marine products had provocated in-depth need for aquaculture farming in such sectors. Still fishes, prawns, and crabs are highly susceptible toward infectious diseases caused by pathogens, namely, bacteria, viruse, and fungal agents. Administration of synthetic chemotherapeutants and antibiotics to prevent and control infections are highly disapproved for their negative impacts such as resistance formation and immunosuppression, and hence, had ended up in reduced preference for antibiotics treated crab population [1]. Diseases caused by bacterial infection in crab causes great economical loss to the crab population. So as to maintain the animal health, several antibiotics have been used to overcome the bacterial diseases which had resulted in the development of resistance among pathogenic agents. There was a significant antibiotic resistance generated by pathogenic bacteria due to repeated uses of antibiotics, and hence, there is an urgent need for researchers to discover new drugs against such pathogenic bacteria. In the past decade, to control microbial diseases, a number of chemotherapeutic agents including synthetic antibiotics are used in crab farms. This had led to serious problems such as antibiotic resistance and decreased survival rates [2-4]. Hence, rather using such chemotherapeutics and synthetic antibiotics, a notable attention is generated for the use of natural immunostimulants from plants to control infectious diseases in aquaculture sectors. Immunostimulants are those groups of biological compounds that can effectively improve the nonspecific cellular and humoral defense mechanism without destructing the base metabolism in animal systems [5]. Medicinal plants, since time immemorial, have been used as a source of medicinal agent altering the immune system. Medicinal plants chosen as immunomodulatory agent must serve as an alternative potential to conventional chemotherapy methods in curing diseases, especially in relation to host defense mechanism. Plant phytochemicals such as flavonoids, tannins, and saponins are responsible for stimulating immune responses in various in vitro animal models by virtue of its antioxidant ability [6]. Salvinia molesta D.S. Mitchell, also known as giant Salvinia, is a genus of floating ferns belonging to the family Salviniaceae, and it is a diversified plant with 10-14 species in world, particularly at the tropics. The plant could double its biomass in 2-3 days under favorable conditions and can stay functional even at dry conditions [7]. The potentially of $S$. molesta to accumulate certain metals and effluent treatment was recently studied and proven, whereas the medical or pharmaceutical potential of giant S. molesta remains still underexplored [8]. Hence, the present study was focused on screening the immunostimulant activity of S. molesta extract in freshwater crab Oziotelphusa senex senex challenged with Aeromonas hydrophila.

\section{METHODS}

Collection of experimental animal and treatment

The male and female crabs, $O$. senex senex, were collected from paddy fields of Thirukazhukundram, Kanchipuram district, Tamil Nadu, and was brought to the laboratory and maintained in plastic tubs. Crabs were fed with beef mutton, and water was changed daily and was acclimatized for 15 days at existing room temperature. The crabs were divided into six groups of thirty crabs each and were subjected to treatment (Table 1). Group A and B are kept as saline-treated control. Groups $\mathrm{C}$ and D are infected with $0.1 \mathrm{ml}$ of $10^{9} \mathrm{cfu} / \mathrm{ml}\left(\mathrm{LD}_{50}\right)$ standard concentration of $A$. hydrophila. Both the groups were allowed to withstand infection for 96 hrs. After 96 hrs of incubation, hemolymph was collected from ten crabs of each group for hematological and immunological assays. Remaining twenty infected crabs were treated 
with $100 \mu \mathrm{l}$ of ethanolic extract of $S$. molesta. Then, Groups E and F were allowed to incubate for 96 hrs. After 96 hrs, hematological and immunological assays were performed for the treated Groups E and F. Simultaneously, similar assays were performed for control Groups A and B.

\section{Collection of hemolymph}

Hemolymph of $O$. senex senex was collected aseptically from the base of one of the second walking legs using a sterile syringe with ice-cold citrate EDTA buffer $(0.45 \mathrm{M} \mathrm{NaCl}$; $0.1 \mathrm{M}$ glucose; $30 \mathrm{mM}$ tri-sodium citrate; 20 mM citric acid; 100 mM EDTA, pH 4.6) as anticoagulant.

\section{Total hemocyte count (THC)}

THC was determined using standard methods of hemocytometer [9].

\section{Differential hemocytes count (DHC)}

DHC was performed using standard methods [10]. The smears were prepared carefully by streaking a drop of hemolymph and thoroughly mixed with hemocyte suspension on glass slides. These films were then air dried, incubated for 5 minutes in methanol. The films were washed in distilled water, washed with Giemsa stain solution for 20 minutes, and finally, rinsed with distilled water. The presence of large granule cells (LGC), small granule cells (SGC), and hyaline cells (HC) were determined.

\section{Immunological assay}

\section{Prophenoloxidase (ProPO) assay}

ProPO activity in hemolymph samples was determined using L- dihydroxyphenylalanine (L-DOPA) as a substrate. Tris-buffered saline (TBS) $(30 \mu \mathrm{l})$ was added to the experimental cuvette containing $30 \mu \mathrm{l}$ of hemolymph sample. Then, $60 \mu \mathrm{l}$ L-Dopa solution $(1.6 \mathrm{mg} / \mathrm{ml}$ in TMS) was added followed by immediate mixing and $200 \mu \mathrm{l}$ of TBS was added as a diluent, and enzyme activity was measured by recording the absorbance of dopachrome at $490 \mathrm{~nm}$ against a blank containing $260 \mu \mathrm{l}$ of TBS and $60 \mu \mathrm{l}$ of L.DOPA. The absorbance value at 1 and 3 minutes after the addition of $200 \mu \mathrm{l}$ of TBS was recorded. Enzyme activity was expressed in units, defined as the amount of enzyme giving an increase in absorbance at $490 \mathrm{~nm}$ of 0.001 per minutes $/ \mathrm{mg} /$ protein [11]. All the obtained data were expressed as mean \pm standard error of mean (SEM).

\section{Statistical analysis}

The statistical analysis system (SPSS version 17.0) software was used to analyze all the data. The data were expressed as mean \pm SEM, and the

Table 1: Grouping of male and female experimental groups.

\begin{tabular}{ll}
\hline Groups & Male/female groups and treatment groups \\
\hline Group A & Control-male crab \\
Group B & Control-female crab \\
Group C & A. hydrophila infected male crab at $96 \mathrm{hrs}$ \\
Group D & A. hydrophila infected female crab at $96 \mathrm{hrs}$ \\
Group E & S. molesta injected to Group C male after $96 \mathrm{hrs}$ \\
Group F & S. molesta injected to Group D female after $96 \mathrm{hrs}$ \\
\hline
\end{tabular}

data were analyzed using the Student's $t$-test and one-way analysis of variance. Differences were considered statistically significant at $\mathrm{p}<0.05$ level.

\section{RESULTS}

THC

When experimental Groups C and D infected with A. hydrophila were assayed for THC after 96 hrs, there were significant changes in hemocyte count. THC of control male and female crabs was $4231 \pm 31.83$ cells/cu.mm and $3728 \pm 27.83$ cells/cu.mm, respectively, whereas it increased to $6341 \pm 28.61$ cells/cu.mm and $6039 \pm 26.41$ cells/cu.mm in infected Groups C and D, respectively. There was an increase in hemocyte counts when compared to control Groups A and B which showed the response of immune defense mechanism against the pathogen. When Groups E and F (Groups treated with ethanol extract of S. molesta) were assayed for THC after 96 hrs of the incubation period, the THC levels decreased significantly to $4604 \pm 34.92$ and $3556 \pm 22.14$ in both male and female groups, respectively, depicting the immune protection of $S$. molesta (Table 2 and Fig. 1).

\section{DHC}

Control Groups A and B when assayed for DHC and the following results were obtained. In that way, the LGC, SGC, and HC ranged as $23 \pm 0.31 \%$, $51 \pm 0.21 \%$, and $28 \pm 0.23 \%$ for male control Group A, whereas LGC, SGC, and HC for female control group ranged as $25 \pm 0.43 \%, 42 \pm 0.93 \%$, and $20 \pm 0.36 \%$, respectively (Table 1). After $96 \mathrm{hrs}$ of exposure to A. hydrophila, the differential hemocyte count, LGC and SGC counts significantly increased, but HC gradually decreased in treated groups (E and F), whereas in $S$. molesta-treated groups, the levels of all the three cell types retained to closer control group values (Table 2)

\section{ProPo activity}

In hemolymph of control crabs of Groups $\mathrm{A}$ and $\mathrm{B}$, the ProPO enzyme activity level recorded was $0.798 \pm 0.021$ and $0.898 \pm 0.016$ (mg/minutes/protein), respectively. After $96 \mathrm{hrs}$ of exposure to A. hydrophila, the ProPO level gradually reduced in infected Group C, namely, $0.321 \pm 0.036$ and Group D, namely, $0.491 \pm 0.026$ (mg/minutes/ protein). When treated Groups E and F are assayed after $96 \mathrm{hrs}$, the ProPO level increased significantly elucidating the role of $S$. molesta in immune induction (Table 2 and Fig. 2).

\section{DISCUSSION}

In the recent times, modern aquaculture farming practices are developed at rapid rate. Still, infectious diseases are posing a major problem in such industry, thus causing heavy loss to farmers [12]. There are numerous naturally occurring herbs that have been reported to possess high antioxidant and anticancer role and have proven to be a potent therapeutic agent $[13,14]$. Hence, herbal immunostimulants can be an effective alternative strategy in lieu of antibiotics and chemotherapies in marine disease management [15]. Ethanolic extract of $S$. molesta, an abundantly available freshwater weed, was proven for its cytotoxic activity against human non-small cell lung cells but not toxic to normal

Table 2: Levels of THC / DHC \& ProPO in experimental groups.

\begin{tabular}{|c|c|c|c|c|c|}
\hline \multirow[t]{2}{*}{ Groups } & \multirow[t]{2}{*}{ THC cells/cu.mm } & $\begin{array}{l}\text { Differential hemocytes } \\
\text { counts (DHC) }\end{array}$ & \multirow[t]{2}{*}{ SGC \% } & \multirow[t]{2}{*}{ HC \% } & \multirow[t]{2}{*}{ ProPo minutes/mg/protein } \\
\hline & & LGC \% & & & \\
\hline B & $3728 \pm 27.83$ & $25 \pm 0.43$ & $42 \pm 0.93$ & $20 \pm 0.36$ & $0.898 \pm 0.016$ \\
\hline $\mathrm{C}$ & $6341 \pm 28.61^{*}$ & $25 \pm 0.65^{* *}$ & $70 \pm 0.32^{*}$ & $15 \pm 0.36^{*}$ & $0.321 \pm 0.036^{*}$ \\
\hline $\mathrm{D}$ & $6039 \pm 26.41^{*}$ & $32 \pm 0.19 *$ & $52 \pm 0.34^{*}$ & $12 \pm 0.65^{*}$ & $0.491 \pm 0.026^{*}$ \\
\hline $\mathrm{E}$ & $4604 \pm 34.92^{*}$ & $21 \pm 0.73^{*}$ & $53 \pm 0.21^{*}$ & $24 \pm 0.46^{*}$ & $0.801 \pm 0.023^{*}$ \\
\hline $\mathrm{F}$ & $3556 \pm 22.14^{*}$ & $23 \pm 0.54 *$ & $45 \pm 0.46^{*}$ & $23 \pm 0.44^{*}$ & $0.853 \pm 0.012 *$ \\
\hline
\end{tabular}

Each value represents mean \pm SEM of three individual observations. Group-A versus $C$ versus $E * p<0.05, * *$ insignificant. Group-B versus $D$ versus $F * p<0.05$,

**insignificant 


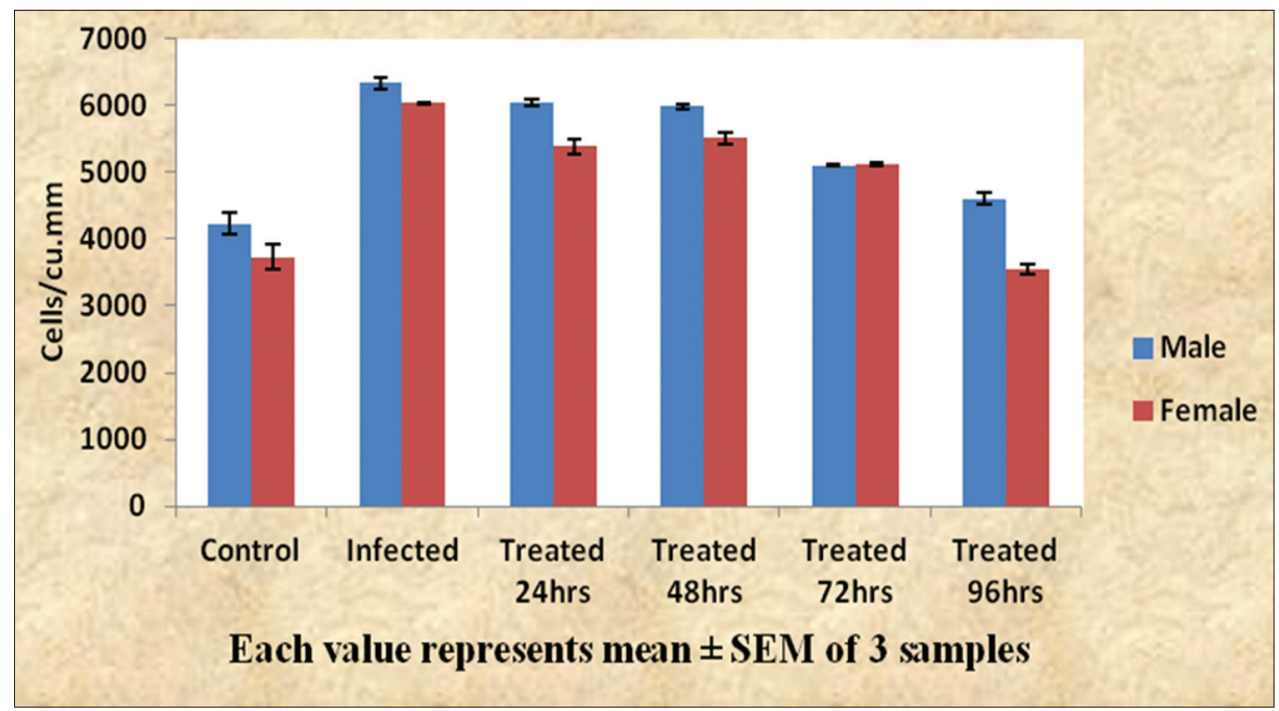

Fig. 1: Total hemocyte count

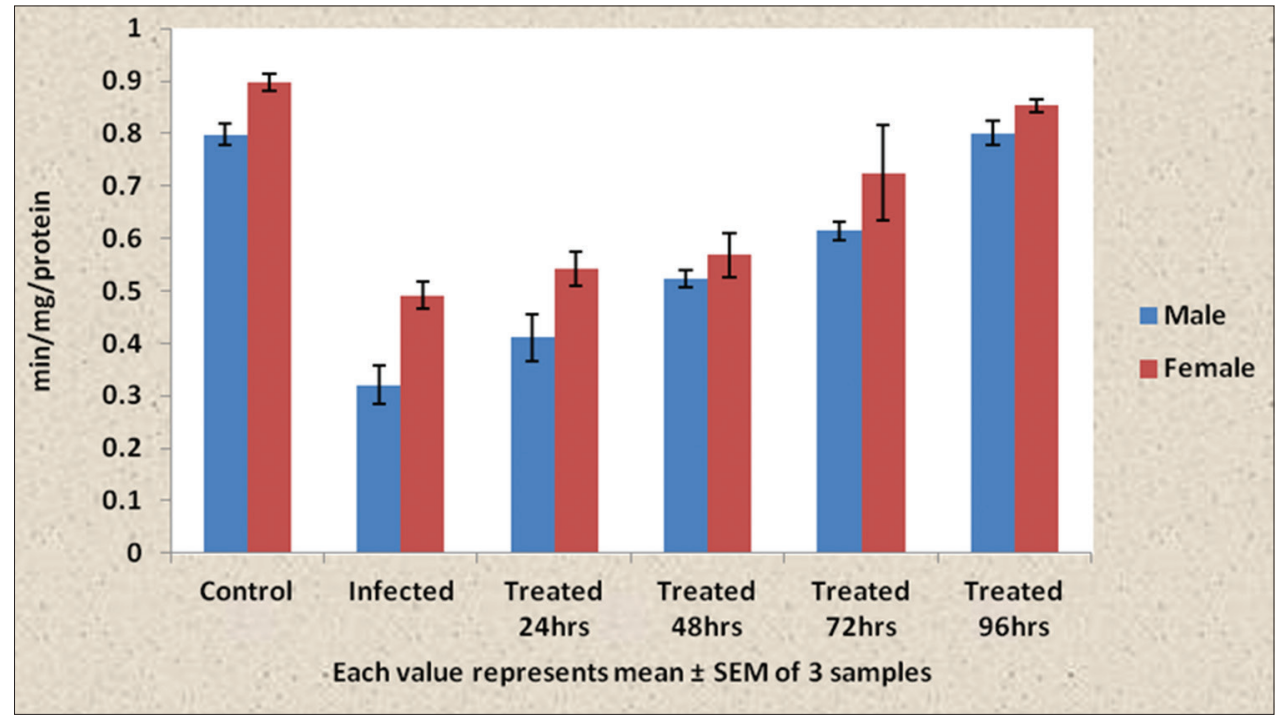

Fig. 2: Prophenoloxidase activity

human lung fibroblasts cells [8]. The previous studies also have proven that $S$. molesta has a potent antioxidant and antibacterial activity against A. hydrophila and is rich in significant phytochemicals [16]. In this way, the present study revealed that administration of ethanolic extract of $S$. molesta in standard concentrations to $O$. senex senex significantly increased innate humoral and cellular responses and disease resistance against $A$. hydrophila bacterial infections. In crustaceans, the vital function of circulating hemocytes in host defense mechanism is the elimination of any foreign particles that can gain access to the hemocoel. This mechanism is exhibited by a combination of phagocytosis, nodule formation, and encapsulation reaction, that depends on the dimension of the foreign bodies [17]. In this study, the hemocyte counts decreased significantly in the 96 hrs infected groups when treated with $S$. molesta which evidenced the immune alteration by the plant supplement. Crustaceans display relatively simple hemocytes that are mainly subdivided into three cell types: Hyaline, semi granular, and granular. These cell types vary not only in morphological features but also in biochemical characteristics and in vitro behavior. The levels of hyaline, semi granular, and granular cells vary according to the taxonomic grouping of the host [18]. In this study, there were significant changes in differential hemocyte count in treated groups after treatment with S. molesta, elaborating its immunostimulant role. ProPO is an inactive precursor of phenoloxidase (PO), and it converts tyrosine to DOPA, as well as DOPA-quinone. The end product of the non-enzymatic reactions that spontaneously formed is melanin, a brown or yellowish pigment. In arthropods, this pigment is produced in the cuticle as a result of a wound or parasitic attack [19]. Thus, infected groups showed a higher level of ProPO activity, whereas, in treated groups, there was observed a significant reduction in ProPO activity. Thus the present study revealed the potential immune protection efficacy of ethanolic extract of $S$. molesta in treated groups ( $\mathrm{E}$ and $\mathrm{F}$ ) of 0 . senex senex.

\section{CONCLUSION}

Since ancient times, medicinal plants have been used in traditional medicine for treatment and control of many diseases. Natural plant products are reported to possess antimicrobial, antibacterial, antioxidant, immunostimulation, and aphrodisiac properties due to the presence of active principle components such as alkaloids, flavonoids, pigments, phenolics, terpenoids, steroids, and essential oils. Thus, plant products with significant and rich sources of immune-enhancing substances are used across developing countries to promote health, to increase the body's natural resistance to infection, and in prevention and treatment of various diseases. Plant products are an inexpensive and economical source of therapeutic medicine, possessing greater 
accuracy than chemotherapeutic agents, and hence, offer a viable solution for all problems which aquaculture face currently. In this way, S. molesta D.S. Mitchell can be utilized as a potent immunostimulant to face the microbial infection challenges in crab farming

\section{REFERENCES}

1. Maqsood S, Singh P, Samoon MH, Munir K. Emerging role of immunostimulants in combating the disease outbreak in aquaculture. Int Aquat Res 2011;3(1):147-63.

2. Asirvatham AB, Sekhar P. Immunological challenge study in a Vibrio harveyi infected freshwater crab, Oziotelphusa senex. Int J Innov Drug Discov 2015;5(2):57-9.

3. Karunasagar I, Karunasagar I, Otta SK. Disease problems affecting fish in tropical environments. J Appl Aquac 2003;13(3-4):231-49.

4. Seethalakshmi I, Jayalakshmi S, Subashkumar R, Swaminathan P, Rajagopal K. Occurrence of multiple antibiotic resistant Aeromonas hydrophila isolated from marketed fish and shrimp samples. Indian J Appl Microbiol 2006;6(1):79-87.

5. Murthy KS, Kiran BR. Review on usage of medicinal plants in fish diseases. Int J Pharm Biol Sci 2013;4(3):975-86.

6. Citarasu T, Rajajeyasekar R, Venketramalingam K, Dhandapani PS, Marian MP. Effect of wood apple Aegle marmelos, Correa (Dicotyledons, Sapindales, Rutaceae) extract as an antibacterial agent on pathogens infecting prawn (Penaeus indicus) lariviculture. Indian J Mar Sci 2003;32(2):156-61.

7. McFarland DG, Nelson LS, Grodowitz MJ. Salvinia molesta D. S. Mitchell (Giant Salvinia) in the United States: A Review of Species, Ecology and Approaches to Management, ERDC/EL SR-04-2. Washington, DC: U.S. Army Corps of Engineers; 2004.

8. Li S, Wang P, Deng G, Yuan W, Su Z. Cytotoxic compounds from invasive giant salvinia (Salvinia molesta) against human tumor cells. Bioorg Med Chem Lett 2013;2:6682-7.
9. Dacie JV, Lewis SM. Practical Heamatology. London: JS Churchill Ltd.; 1968. p. 568.

10. Kondo M. Experiments of Body Defence Mechanisms in Crustacean. Shimonoseki, Japan: Institute of Applied Aquabiology, National Fisheries University; 2003. p. 1-13.

11. Takahashi $Y$, Kondo $M$, Itami $T$, Honda $T$, Inagawa $H$, Nishizawa $T$, et al. Enhancement of disease resistance against Penaeid acute viraemia and induction of virus-inactivating activity in haemolymph of kuruma shrimp, Penaeus japonicus, by oral administration of Pantoea agglomerans lipopolysaccharide (LPS). Fish Shellfish Immunol 2000;10:555-8.

12. Kumar IV, Chelladurai G, Veni ST, Peeran SH, Mohanraj J. Medicinal plants as immunostimulants for health management in Indian cat fish. J Coast Life Med 2014;2(6):426-30.

13. Sumalatha D, Nithya TG. Evaluation of in vitro anti-oxidant and anticancer activity of Coriandrum sativum against human colon cancer ht-29 cell lines. Int J Pharm Pharm Sci 2014;2(6):83-6.

14. Pandey G, Verma KK, Singh M. Evaluation of phytochemical, antibacterial and free radical scavenging properties of Azadirachta indica (neem) leaves. Int J Pharm Pharma Sci 2014;6(2):444-7.

15. Harikrishnan R, Balasundaram C. In vitro and in vivo studies of the use of some medicinal herbals against the pathogen Aeromonas hydrophila in goldfish. J Aquat Anim Health 2008;20(3):165.

16. Nithya TG, Jayanthi J, Raghunathan MG. Phytochemical, antibacterial and GC MS analysis of a floating fern Salvinia molesta D.S. Mitchell (1972). Int J Pharmtech Res 2015;8(9):85-90.

17. Aladaileh S, Nair SV, Birch D, Raftos DA. Sydney rock oyster (Saccostrea glomerata) hemocytes: Morphology and function. J Invertebr Pathol 2007;96:48-63.

18. Smith VJ, Chisholm JR. Non-cellular immunity in Crustaceans. Fish Shellfish Immunol 2007;2:1-31.

19. Ratcliffe NA, Rowley AF, editors. Invertebrate Blood Cells. London, New York: Academic Press; 1981. p. 625-8. 